\title{
The Development of Instrument of Reading Literacy Assessment on Indonesian Language Learning in Quality Medan University
}

\author{
Yohana $^{1}$, Mutsyuhito Solin ${ }^{2}$, Wisman Hadi² \\ ${ }^{I}$ Master Student in State University of Medan (Unimed), Medan, Indonesia \\ ${ }^{2}$ Lecturer in State University of Medan (Unimed), Medan, Indonesia
}

\begin{abstract}
This study is aimed to describe the development of instrument of reading literacy assessment on Indonesian language learning in Quality Medan University. The assessment instrument which is developed in the form of a guidebook of reading literacy on the PISA reference which is used as a handbook for lecturers in the field of learning studies reading texts. The population of this study is the first semester students of the Medan Quality Private University. The authors took a sample of 30 students. The result shows that the development of reading literacy assessment instrument on the PISA reference, is a direct assessment because students immediately show evidence of mastery of competencies when the assessment is conducted. The use of reading literacy assessment increases the results of high-level understanding of students, this is indicated by the results of student scores after using the reading literacy assessment on the PISA reference was 2283 compared to the results before 1364.
\end{abstract}

Keywords : development; reading literacy assessment; Indonesian language learning

\section{Introduction}

The availability of literacy literacy resources is an important factor in the world of higher education. Literacy sources read in the world of higher education, one of which is the library. The classic statement said that the library is the center of the availability of various sources for reading for the college which is also referred to as the heart of the university. But if the involvement and unwillingness to use the library or provided outside the library. This is supported by Riska's research (2016: 93) with the title Building a Culture of Information Literacy for Campus Communities, volume 3 states that libraries are a source of information, educational media, recreational media and research media for the community. The library is also a place to store, collect collections of books, printed materials, and other records for the benefit of the general public.

Literacy reading in the world of higher education is a collection of skills that are generic and can be applied in all fields of science. Literacy reading is the basis of lifelong learning in a learning environment for all levels of educational units. With reading literacy students are able to expand, direct themselves and have better control of the learning process they face. Research in reading literacy according to Abidin, et al. (2017: 226) says the basic principle of literacy assessment both mathematical literacy, scientific literacy, literacy, and literacy is an assessment of critical thinking skills, creative thinking, and problem solving thinking.

Assessment in higher education consists of assessing the process of acquiring, applying knowledge and skills, through a learning process that shows students' abilities in processes and products. The model assessment is the main activity, namely the lecturer gives the task, the student shows his performance, and and is assessed based on certain indicators using the instrument, namely the rubric.

Rubric is an assessment guide that describes the criteria used by lecturers in assessing a student's learning outcomes. The function of using performance appraisal rubrics is as observations and criteria for granting scores / ability scores used by students. Regarding this 
matter Permendikbud number $81 \mathrm{~A}$ in 2013 , learning activities are directed at empowering all potential students to become the expected competencies.

\section{Review of Literatures}

\subsection{Reading Literacy}

The word literacy comes from English, namely literacy, which means the ability to read and write. Literacy that comes from the Latin word is littera which means letter or letter, and literacy is translated as hururf literacy. Literacy according to Peter Salim in the dictionary The Contemporary Englis Indonesia Dictionary is the ability to read and write. Carolline (2000: 2) states the literacy of how young children learn to read and write. Graff argues that literacy is a person's ability to read and write, while people have both literate abilities. Whereas Stripling (in Suherli: 2009) states, "Literacy means being able to understand new ideas well enough to use them when needed. Literacy means how to learn. "Literacy is a person's ability to understand, use and reflect written reading to achieve goals as needed, develop knowledge and potential, and participate in society.

Sari (2016: 226) said that the use of literacy is a form of integration of listening, speaking writing, reading and critical thinking. Therefore, as a student, they must be able to get out of their comfort zone, not only that they also have to carry out the tasks given to them not only as a matter of responsibility, but as a pleasure or hobby that will produce maximum results.

Literacy can be said as the ability to read and write then literacy develops again into the ability to read, write, speak and listen. As the times evolved the meaning and focus of literacy changed from a narrow understanding to a broader understanding. Kalantzis (in Endah \& Nurhadi, 2017: 157) says literacy at the beginning of its appearance is interpreted as literacy or literacy which focuses primarily on the ability to read and write, two skills that are the basis for literacy in various ways.

\subsection{Stages of Development of Reading Literacy Assessment Instruments}

Reading literacy assessment instruments must be developed based on the expected task. This of course needs to be set in advance the standards that need to be mastered by students. Next set the criteria to be assessed, namely the rubric that will be used to assess the work of students.

OECD (in Burhan 2016: 420) states that reading literacy assessment is developed based on three main things, namely situation, text, and aspects. The situation is used to determine the text and related tasks that refer to the context and its use built by the text writer. Text (context), which is a variety of reading material tested, both printed text and digital text. Aspects (processes) that refer to cognitive strategies that determine how readers engage or handle text.

Umamy (2012: 1) said the development procedure was carried out in three stages, namely product development, product development, and product testing. "In the pre-development stage, the final result was product specifications. In the development phase, the main activity was to develop product specifications into products in the form of literacy assessment instrument reads PISA The description of the assessment instrument includes 5 parts, namely (1) lattice of reading literacy assessment instruments with PISA references, (2) introductory questions, (3) question instructions, (4) questions items, and (5) assessment rubric.

\subsection{Comparison of Reading Literacy Assessment with Conventional Assessment}


Musfiroh and Litsyorini (2016: 2) with the title construct of literacy competency for elementary school students, volume 15 , said that the reading aspect of learning was determined by PISA, namely by measuring literacy aspects as follows: understanding, using, and reflecting in written form. Specifically the reading competence used is the ability of students to obtain information, interpret the text and reflect on the text. Conventional assessment requires students to have a number of knowledge and skills.

In order to find out whether or not the goal is achieved, it is necessary to assess how much knowledge and skills are satisfactory or unsatisfactory. Then, an assessment is developed to see the achievement of the applicable curriculum standard assessment. While the assessment of reading literacy according to Burhan (2016: 421) states that in broad outlines five processes can be demonstrated for reading assessment tasks, namely taking information, forming broad understanding, developing interpretation, reflecting and evaluating texts, and reflecting and evaluating text forms. So, in other words reading literacy assessment includes the competence to take and understand information, identify and use, reflect and evaluate the texts being tested, and relate them to their own experiences.

\subsection{Assessment in IQF}

Law Number 20 of 2003 concerning the National Education System, the curriculum is defined as "a set of plans and arrangements regarding the purpose, content, and material of learning and the methods used as guidelines for the organizers of learning activities to achieve certain educational goals. Nurdin and Adriantoni (2016: 129) said that the Indonesian National Qualifications Framework (KKNI) is a framework for competency qualification that can juxtapose, equalize and integrate the fields of education with work training and work experience in order to provide recognition of work competencies in accordance with work structures in various sector. KKNI is a national reference to improve the quality and competitiveness of the Indonesian people in the HR sector through the achievement of HR qualifications produced by the education system, national job training systems, and systems

The Indonesian National Qualifications Framework (KKNI) consists of 9 qualification levels, starting from qualification 1 as the lowest qualification and qualification 9 as the highest qualification. The juridical basis for implementing and implementing the Indonesian National Qualifications Framework (KKNI) in the education sector, namely:

1. Presidential Regulation (PERPRES) Number 08 of 2012, concerning the Indonesian National Qualifications Framework (KKNI).

2. Minister of Education and Culture Number 73 of 2013 concerning Implementation of IQF in Higher Education.

Equalization of learning outcomes generated through education with the IQF qualification level:

1. Graduates of basic education are equivalent to level 1;

2. The lowest secondary education graduate is equivalent to level 2;

3. The lowest diploma 1 graduate is equivalent to level 3;

4. The lowest diploma 2 graduate is equivalent to level 4;

5. The lowest diploma 3 graduate is equivalent to level 5;

6. Graduates with diplomas 4 or Applied and Undergraduate Bachelor lowest equivalent to genes

7. The lowest Applied and Masters Masters graduates are equivalent to level 7;

8. Applied and Doctoral Doctorate graduates equivalent to level 9;

9. Graduates of professional education with 7 or 8 levels;

10. Graduates of specialist education are equivalent to levels 8 or 9 . 
The profile of graduates reflects the minimum ability that must be mastered by students after graduation which refers to four aspects of need (1) attitude or attitude, (2) field of work ability, (3) knowledge, and (4) managerial and responsibility. The four abilities must be translated into learning outcomes in each subject of each study program. So that later, all learning plans or Semester Implementation Plans (RPS) must be based on learning outcomes (Learning Outcome) that are in accordance with the needs of the graduation profile.

Imroatus study (2016: 21) with the title of developing a curriculum model for education in English based on KKNI volume 8, said the undergraduate program according to KKNI is Qualification 6, and has the following rights and responsibilities: (1) able to publish the final assignment or work / design / art / model that can be accessed by the academic community, (2) able to be responsible for work in the field of expertise independently and can be given responsibility for the achievement of work results of institutions or organizations with emphasis on safety and job security, (3) able to make appropriate decisions in supervising and evaluation of the work it is responsible for, (4) being able to manage self-learning, (5) being able to communicate information and ideas through various media to the community in accordance with their fields of expertise, (6) being able to develop and maintain a network.

\subsection{PISA (Program for International Student Assessment)}

PISA is a study coordinated by OECD countries (organization for Economic Cooperation and Development). The PISA study aims to see the effectiveness of the education system with an international perspective. PISA is designed to collect information through assessment.

PISA orientation reflects changes in curriculum goals and objectives, which pay more attention to what students can do from what they have learned. Therefore, students are required to have literacy skills.

The focus of PISA is to read and students are assessed on this skill so that their level of understanding is higher. Based on data on the condition of literacy skills of Indonesian students who are still far away at the lower level, a study of the characteristics of reading problems in the international PISA program was conducted from 2000 to 2009. Thus, a complete picture of the characteristics of literacy questions can be obtained.

PISA seeks to measure how well adults, young people, approach the end of compulsory education ready to meet challenges. The assessment focuses on the ability of young people to use their knowledge and skills to meet life's challenges not only to the extent to which they have mastered the existing curriculum.

Table 1. Seven Levels of Reading Ability

\begin{tabular}{|l|l|}
\hline No & Seven Levels of Reading Ability \\
\hline 1 & $\begin{array}{l}\text { Tasks at this level require the reader to find a part of information that is explicitly } \\
\text { stated in a prominent position in a short time, the text is syntactically simple with } \\
\text { the context and type of text familiar to the reader, such as a narrative or a simple } \\
\text { list. }\end{array}$ \\
\hline 2 & $\begin{array}{l}\text { The task at this level requires the reader: to find one or more independent } \\
\text { information explicitly stated; to recognize the main theme or purpose of the } \\
\text { author in the text about a familiar topic, or to make a simple connection between } \\
\text { information in the text and general knowledge everyday. }\end{array}$ \\
\hline 3 & $\begin{array}{l}\text { Some tasks at this level require the reader to find one or more information, which } \\
\text { may need to be concluded and may have to fulfill several conditions. }\end{array}$ \\
\hline
\end{tabular}




\begin{tabular}{|l|l|}
\hline 4 & $\begin{array}{l}\text { Tasks at this level require the reader to find, and in some cases recognize the } \\
\text { relationship between some information that must meet several conditions. } \\
\text { Interpretative tasks at this level require the reader to integrate several parts of the } \\
\text { text to identify the main idea, understand the relationship or interpret the meaning } \\
\text { of a word or phrase. }\end{array}$ \\
\hline 5 & $\begin{array}{l}\text { The task at this level is the acquisition of information that requires the reader to } \\
\text { search for and organize some information that is part of another set of } \\
\text { information. Some tasks at this level require the interpretation of the nuances of } \\
\text { the language in the text by observing the entire text }\end{array}$ \\
\hline 6 & $\begin{array}{l}\text { The task at this level is in the form of gathering information that requires the } \\
\text { reader to search for and arrange some information that is integrated with so many } \\
\text { other information, then concludes which information is considered relevant. }\end{array}$ \\
\hline 7 & $\begin{array}{l}\text { Tasks at this level usually require the reader to make detailed and precise } \\
\text { conclusions, comparisons and contrasts. Such tasks require a complete and } \\
\text { detailed understanding of one or more texts and may involve the integration of } \\
\text { more than one text information. }\end{array}$ \\
\hline
\end{tabular}

(PISA, 2009: Vol. I: 37)

\section{Research Methods}

The study was conducted at the Medan Quality Private University, located on Jl. Ngumban Surbakti No. 18, Sempakata, Medan Selayang, Medan City, North Sumatra. The research will be conducted in even semester T.P 2017/2018.

Bungin (2013: 101) suggests that the population is "the whole (universe) of the object of research which can be in the form of humans, animals, plants, air, symptoms, values, events, attitudes of life, etc. so that these objects can become data sources research". The population of this research and development is the first semester students of the Medan Quality Private University. Arikunto (2013: 174) argues that samples are partially or representative of the population studied. To see the effectiveness of the products developed, researchers only take samples using random sampling techniques, or random samples, or mixed samples. The researcher took a sample of 30 students.

\section{Discussions}

The process of developing reading literacy assessment instruments shows the speed and understanding of reading student texts is still below the average. This shows that students need reading literacy assessment instruments in reading texts. This proves that reading learning has only focused on $5 \mathrm{~W}+1 \mathrm{H}$ reading instruments. this requires this assessment instrument as an alternative to assist students in reading learning.

The assessment instrument developed in the form of a reading literacy assessment manual on the PISA reference is used as a handbook for lecturers in the field of learning to read texts. The material used in learning is reading material. This reading literacy assessment guide book will make it easier for lecturers to use the types of assessments that will be adapted to the material used through cognitive aspects, and skills. 
Table 1. Data Requirement Analysis

\begin{tabular}{|c|c|c|c|c|c|c|}
\hline No & Type of information & Answer & \multicolumn{4}{|c|}{ Frequency } \\
\hline \multirow{3}{*}{1} & \multirow{3}{*}{$\begin{array}{l}\text { Get to know the reading } \\
\text { literacy assessment } \\
\text { instrument that has been } \\
\text { developed }\end{array}$} & & Lecturer & $\%$ & Students & $\%$ \\
\hline & & Yes & 1 & $50 \%$ & 12 & $37,50 \%$ \\
\hline & & No & 1 & $50 \%$ & 20 & $62,50 \%$ \\
\hline \multirow[b]{2}{*}{2} & \multirow{2}{*}{$\begin{array}{l}\text { Using reading literacy } \\
\text { assessment instruments } \\
\text { developed in the learning } \\
\text { process }\end{array}$} & Yes & 1 & $50 \%$ & 4 & $12,50 \%$ \\
\hline & & No & 1 & $50 \%$ & 28 & $87,50 \%$ \\
\hline \multirow[b]{2}{*}{3} & \multirow{2}{*}{$\begin{array}{l}\text { Requires reading literacy } \\
\text { assessment instruments on } \\
\text { PISA references in the } \\
\text { reading learning process }\end{array}$} & Yes & 2 & $100 \%$ & 30 & $93,75 \%$ \\
\hline & & No & 0 & 0 & 2 & $6,25 \%$ \\
\hline
\end{tabular}

The results of the questionnaire distributed to lecturers and students were obtained as follows:

1) Some lecturers (50\%) stated that they did not understand the reading literacy assessment instrument in the PISA reference while the majority of students (37.50\%) did not know the reading literacy assessment instrument on the PISA reference.

2) Some teachers $(50 \%)$ stated that they did not use a variation of the literacy assessment instrument read on the PISA reference on the material used in the learning process, while the majority of students were $62.50 \%$ stated that they did not use the variation of the assessment given by the lecturer in the assessment.

3) All Indonesian language lecturers (100\%) stated the need for a guidebook for reading literacy assessment instruments in the PISA reference so that the lecturers would recognize and explore reading literacy assessment instruments on the PISA reference in text reading material while the majority of $93.75 \%$ students needed literacy assessment instruments read on the PISA reference.

The next step is to conduct a literature survey. The results of the literature survey show that at this time the reading literacy assessment instrument used by Indonesian Language lecturers at the University of Quality Medan is only using $5 \mathrm{~W}+1 \mathrm{H}$ ratings.

The final step, developing a product for literacy assessment instruments, reads on the PISA reference in the material reading the text. Product development produces or creates a reading literacy assessment instrument guide book on the PISA reference to the material of speed reading and understanding of the reading text. A guidebook that will be used by lecturers to help lecturers' understanding of literacy reading instruments. In addition, lecturers will use varied assessment instruments according to the material that will be used by lecturers in learning. Furthermore, the product will be validated according to its field before being used to the research site.

The initial product development phase was carried out, namely the validation of material content, evaluation validation, product revisions and passing evaluations and suggestions from lecturers. Based on the stages of development of Borg and Gall (in Tegeh et al., 2014: 7) this 
stage is the development stage to obtain input from material experts, experts on evaluation, assessment and advice from Indonesian Language lecturers at Quality universities.

The initial product of the reading literacy assessment instrument developed was a reading literacy assessment instrument in the PISA reference in the form of a speed reading assessment guide book and the comprehension of the reading text in general contained the following:

1) Preface

2) Table of contents

3) Concept of reading literacy assessment on PISA references

4) Learning Activities

The learning activities are arranged based on achievement indicators from the text reading material consisting of explanations of speed reading and reading text comprehension.

5) Evaluation

6) Bibliography

The next step, the reading literacy assessment instrument in the PISA reference developed was validated by a team of material experts, evaluation experts, and responses from Indonesian lecturers. The following stages will be described as follows:

\section{1) Material Validation}

The validation of the reading literacy assessment instrument in the PISA reference aims to obtain information that will be used to improve the quality of the reading literacy assessment instrument developed in accordance with reading material. Validation of material experts conducted by Prof. Dr. Khairil Ansari, M.Pd and Drs. Pandapotan Tambunan, M.Pd. validation begins with a discussion between the researcher and the validator. The researcher will explain the product that is produced then the validator will assess the results of the product of the researcher.

The material validation expert examined the reading literacy assessment manual provided by the researcher. The material validation expert will examine the contents of the product and provide direction to the researcher so that the reading literacy research guidebook products are produced well. The researcher will revise the reading literacy assessment manual according to the input of the validation expert. Then the researcher conducted a discussion again with material experts to check the quality of the products produced.

\section{2) Validation of Evaluation Experts}

Expert evaluation validation was conducted by Prof. Dr. Sumarno, M.Pd. and Dr. Surya Masniari Hutagalung, M.Pd. validation is done to obtain information that will be used to improve the quality of the reading literacy assessment instrument developed in accordance with the aspects that exist in the assessment of learning in the form of feasibility of presentation. Validation results in the form of assessment scores from several aspects of the assessment indicators that exist in the instruments developed.

The assessment of Indonesian language lecturers on product development guidebooks for reading literacy assessment instruments in the PISA reference was carried out by Drs. Pandapotan Tambunan, M.Pd, a lecturer at the private university of Qualiti Medan. This assessment takes the form of a guidebook by introducing reading literacy assessment instruments then describing the material of student learning achievement indicators. This is done to obtain information that will be used to improve the quality of the assessment guidebook that has been developed. The results of the assessment are in the form of scores on learning 
components that are in accordance with Indonesian language learning especially in the material of speed reading and understanding of reading texts.

The results of the responses or responses made by Indonesian Language lecturers concluded that the assessment instrument in the form of a reading literacy assessment instrument in the PISA reference reading material included in the criteria of "very good" with a total percentage of $92 \%$. The response from the Indonesian language teacher to the reading literacy assessment instrument guidebook on the PISA reference can be seen in the following table:

Table 2. Responses from Indonesian Language Lecturers towards the Reading Literacy Assessment Instrument

\begin{tabular}{|l|l|l|l|}
\hline No & Indicators & $\begin{array}{l}\text { Average } \\
\text { Score (\%) }\end{array}$ & Criteria \\
\hline 1 & The overall guidebook appearance is interesting & $88 \%$ & Very good \\
\hline 2 & $\begin{array}{l}\text { The language used in the guidebook is easy to } \\
\text { understand }\end{array}$ & $100 \%$ & Very good \\
\hline 3 & $\begin{array}{l}\text { The material in the guidebook is structured } \\
\text { systematically }\end{array}$ & $88 \%$ & Very good \\
\hline 4 & $\begin{array}{l}\text { The concept of literacy assessment reading in the } \\
\text { introduction is clear and easy to understand }\end{array}$ & $75 \%$ & Good \\
\hline 5 & $\begin{array}{l}\text { Learning activities stimulate students' critical } \\
\text { thinking skills }\end{array}$ & $88 \%$ & Very good \\
\hline 6 & $\begin{array}{l}\text { The type of instrument assessment in the module } \\
\text { varies }\end{array}$ & $88 \%$ & Very good \\
\hline 7 & $\begin{array}{l}\text { Information in the guidebook is in accordance with } \\
\text { the development of science and technology }\end{array}$ & $88 \%$ & Very good \\
\hline 8 & $\begin{array}{l}\text { The assessment instrument helps students improve } \\
\text { their reading speed and high understanding }\end{array}$ & $88 \%$ & Very good \\
\hline 9 & $\begin{array}{l}\text { Instrument assessment can be studied independently } \\
\text { by the lecturer }\end{array}$ & $100 \%$ & Very good \\
\hline 10 & $\begin{array}{l}\text { Assessment instruments make it easier for teachers to } \\
\text { evaluate students }\end{array}$ & $88 \%$ & Very good \\
\hline
\end{tabular}

The results of the lecturers' response to the reading literacy assessment instrument in the PISA reference on the reading material developed had a total percentage of $92 \%$ with the criteria of "Very Good". This means that the reading literacy assessment instrument in the form of a guidebook on reading material in the PISA reference developed meets the demands of learning to be taught to students in the class.

The results of individual trials, namely the perceptions of students towards reading literacy assessment instruments that are compiled or developed. The purpose of this individual trial was to find out the initial opinions of students as users before a small group test of the product developed in the second semester students of Quality Medan University. Data from individual test student responses to literacy reading assessment instruments can be seen from table 3 below: 
Table 3. Data from Individual Test Student Responses to Literacy Reading Assessment Instrument

\begin{tabular}{|c|c|c|c|}
\hline No & Assessment Indicator & Precentage & $\begin{array}{l}\text { Assessment } \\
\text { Criteria }\end{array}$ \\
\hline $\mathbf{A}$ & $\begin{array}{c}\text { Literacy Reading Assessment } \\
\end{array}$ & & \\
\hline 1 & $\begin{array}{l}\text { Helping students understand from aspects of } \\
\text { assessment }\end{array}$ & $100 \%$ & Very good \\
\hline 2 & $\begin{array}{l}\text { Assessment guides are prepared in accordance } \\
\text { with the objectives of speed reading and high- } \\
\text { level learning }\end{array}$ & $88 \%$ & Very good \\
\hline 3 & $\begin{array}{l}\text { The assessment guide is in accordance with the } \\
\text { material being studied so that students can easily } \\
\text { understand it }\end{array}$ & $100 \%$ & Very good \\
\hline 4 & $\begin{array}{l}\text { Variation of instruments helps students better } \\
\text { understand the material of speed reading and a } \\
\text { high level of understanding of poetry }\end{array}$ & $75 \%$ & Good \\
\hline 5 & $\begin{array}{l}\text { The assessment manual provides feedback to } \\
\text { students and lecturers }\end{array}$ & $100 \%$ & Very good \\
\hline 6 & $\begin{array}{l}\text { The assessment guide helps students know the } \\
\text { level of reading ability and speed reading and high } \\
\text { level comprehension }\end{array}$ & $75 \%$ & Good \\
\hline 7 & $\begin{array}{l}\text { The assessment guide can access student } \\
\text { understanding and reasoning during learning }\end{array}$ & $88 \%$ & Very good \\
\hline $\mathbf{B}$ & Language and Instrument Writing & & \\
\hline 1 & $\begin{array}{l}\text { Use language that is in accordance with EYD and } \\
\text { easy to understand }\end{array}$ & $100 \%$ & Very good \\
\hline 2 & Consistent use of fonts (letters) looks neat & $75 \%$ & Good \\
\hline 3 & $\begin{array}{l}\text { The use of row spacing and spaces is neatly } \\
\text { arranged and consistent }\end{array}$ & $100 \%$ & Very good \\
\hline 4 & $\begin{array}{l}\text { The typing layout and table shape are neatly } \\
\text { arranged so that it is easy to understand variations } \\
\text { in instruments }\end{array}$ & $88 \%$ & Very good \\
\hline $\mathbf{C}$ & Student Learning Activities & & \\
\hline 1 & The guidebook helps students learn independently & $100 \%$ & Very good \\
\hline 2 & $\begin{array}{l}\text { Increasing student participation in practicum on } \\
\text { speed reading and high-level material }\end{array}$ & $88 \%$ & Very good \\
\hline 3 & $\begin{array}{l}\text { Improving student performance in the application } \\
\text { of reading fast reading and high level } \\
\text { understanding in everyday life }\end{array}$ & $100 \%$ & Very good \\
\hline & Average score & & Very good \\
\hline
\end{tabular}

Small group tests were carried out on 9 students of the Quality Medan University. The evaluation of this small group trial became an advanced stage of product testing on 3 students. Further trials were conducted on 9 students to see an increase in the use of reading literacy assessment manuals. The thing that the lecturers did on individual trials was the same as the 
small group trials. Then students will give an assessment according to the questionnaire given by the researcher. The researcher will provide guidance to students before giving an assessment so that students understand the contents of the questionnaire. The researcher will give time to students to provide questionnaire assessments and conduct discussions with lecturers. The discussion took the form of directors and input between lecturers and researchers to find out the development of students from the learning outcomes. The learning results are the student's grades from the assignments given by the lecturer according to the instructions for the literacy assessment guide reading on the PISA reference in the material of speed reading and high understanding in reading the text.

The large group test was conducted on 32 second semester students at Quality Medan University. The large group trial is the last test to see the level of use of the product in the form of a literacy assessment manual reading on the PISA reference in the material reading the text. Lecturers will carry out the same learning process with individual trials and large group trials. The researcher must know the level of understanding of the lecturer towards the reading literacy assessment instrument. The same thing was done in individual trials and small group trials. This is aimed at avoiding the gap in the perceptions of lecturers and students after using the reading literacy assessment book product on the PISA reference. . Therefore, before the trial, researchers and lecturers conducted a discussion on the literacy assessment manual to read the PISA reference on reading material.

Validation of material experts conducted by Prof. Dr. Khairil Ansari, M.Pd and Drs. Pandapotan Tambunan, M.Pd. validation is done to obtain information that will be used to improve the quality of reading literacy assessment instruments developed in accordance with reading material. The results of the validation can be illustrated in the diagram below.

Figure 1. Average Score of Material Experts on the Reading Literacy Assessment Instrument on Reading Materials

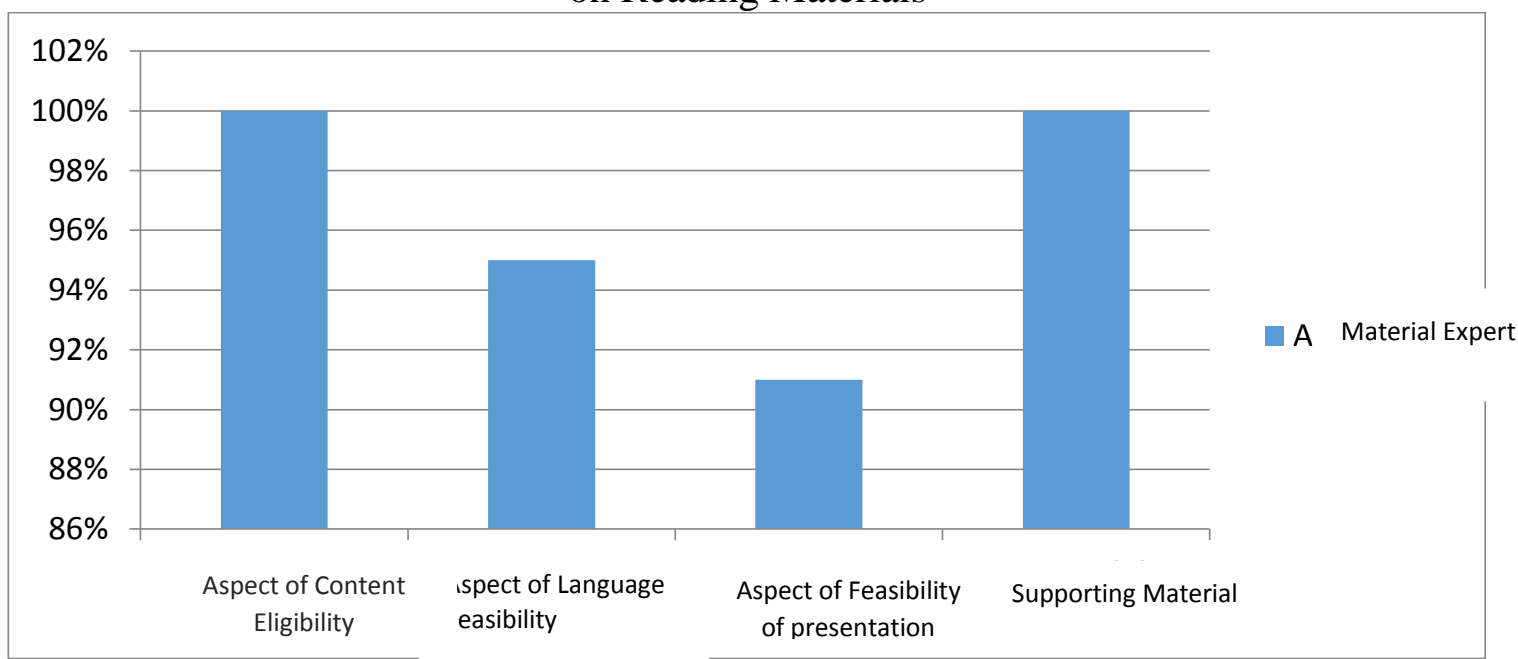

The results showed that the presentation of the aspects of content eligibility namely $100 \%$ entered into a very good category, the language feasibility aspects namely $95 \%$ with very good categories, the feasibility aspect of presentation had a percentage of $91 \%$ with very good categories, and supporting material had presentations of $100 \%$ with a very good category. The overall average is $96 \%$ in the very good category. It can be concluded that the reading literacy assessment instrument can be used for assessment of reading material, but there are still many improvements, especially for supporting material indicators in order to assess students' ability 
and level of understanding of learning to read texts, so they can know the achievement of learning objectives of each student.

Expert evaluation validation was conducted by Prof. Dr. Sumarno, M.Pd. and Dr. Surya Masniari Hutagalung, M.Pd. validation is done to obtain information that will be used to improve the quality of the reading literacy assessment instrument developed in accordance with the aspects that exist in the assessment of learning in the form of feasibility of presentation. Validation results in the form of assessment scores from several aspects of the assessment indicators that exist in the instruments developed. The results of the validation can be illustrated in the diagram below.

Figure 2. Percentage of Average Evaluation Expert Scores on the Reading Literacy Assessment Instrument on Quick Reading Material and Understanding

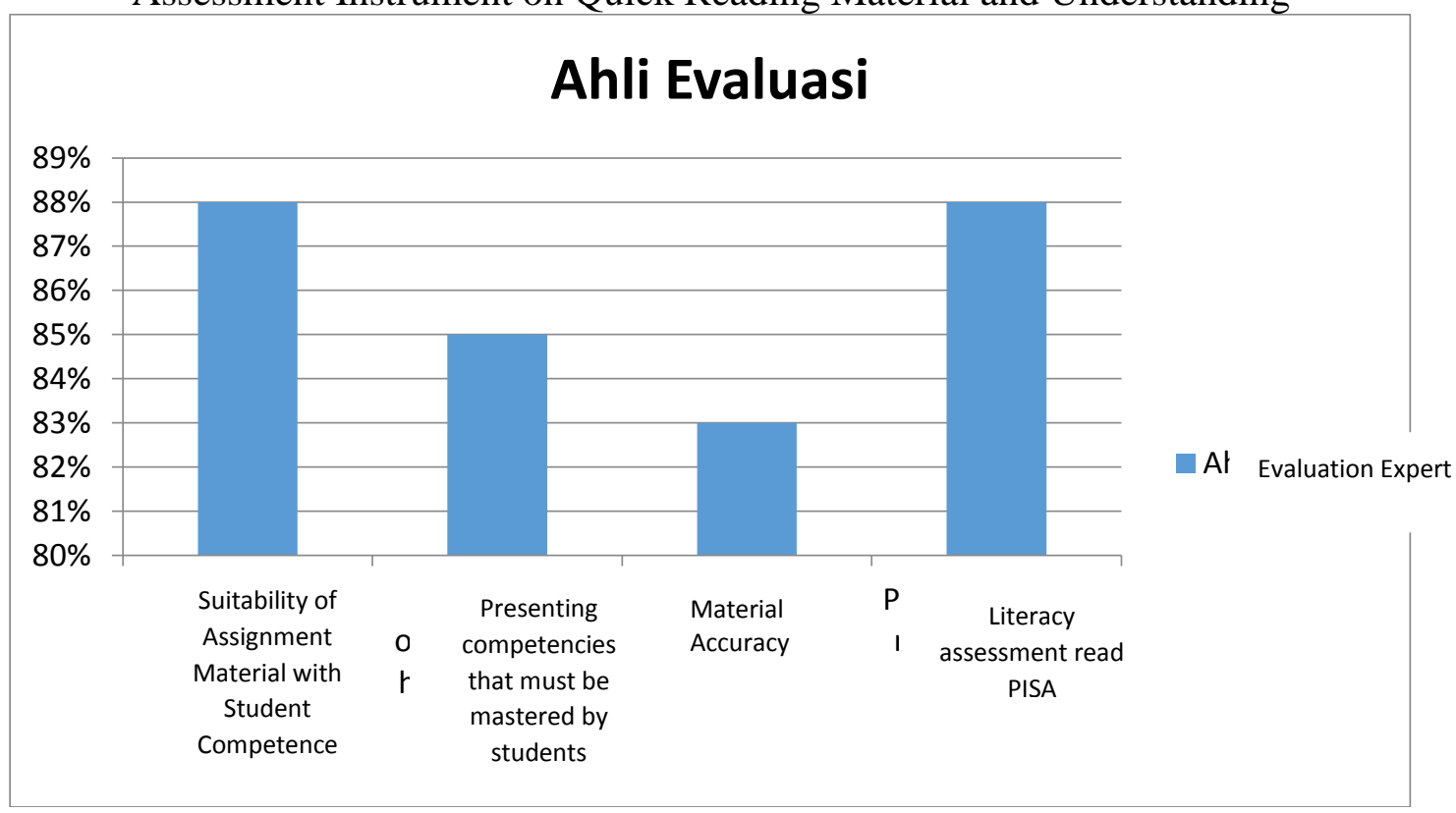

The results of the assessment indicate that the percentage of suitability of the assignment material with student competency $88 \%$ entered into the excellent category, presenting competencies that must be mastered by $85 \%$ students with very good categories, material accuracy had a percentage of $83 \%$ with very good categories and reading literacy assessments had a percentage that is $88 \%$ with a very good category. With an overall average of $85 \%$ in the excellent category. Based on the above results, it can be concluded that the reading literacy assessment instrument on PISA can be used to assess reading material.

The test results of the use of student learning on the development of literacy assessment instruments read on PISA in reading material were carried out at Quality Medan Private University which was tested for second semester students using tests. The tests carried out are classified into two types of tests, namely pretest and posttest. The results of the recapitulation of data obtained from the pretest and posttest can be described in table 5 below. 
Table 4. Recapitulation of Data on Learning Outcomes Pretes and Postes on Reading Material for Second Semester Students at Quality Medan University

\begin{tabular}{|c|c|c|}
\hline No. Student & Pretes & Postes \\
\hline Student 1 & 36 & 74 \\
\hline Student 2 & 24 & 63 \\
\hline Student 3 & 47 & 51 \\
\hline Student 4 & 18 & 58 \\
\hline Student 5 & 21 & 57 \\
\hline Student 6 & 42 & 77 \\
\hline Student 7 & 61 & 60 \\
\hline Student 8 & 44 & 61 \\
\hline Student 9 & 61 & 73 \\
\hline Student 10 & 22 & 41 \\
\hline Student 11 & 39 & 72 \\
\hline Student 12 & 48 & 72 \\
\hline Student 13 & 39 & 81 \\
\hline Student 14 & 44 & 62 \\
\hline Student 15 & 44 & 71 \\
\hline Student 16 & 23 & 81 \\
\hline Student 17 & 22 & 79 \\
\hline Student 18 & 36 & 65 \\
\hline Student 19 & 21 & 75 \\
\hline Student 20 & 22 & 69 \\
\hline Student 21 & 17 & 53 \\
\hline Student 22 & 48 & 69 \\
\hline Student 23 & 47 & 51 \\
\hline Student 24 & 61 & 84 \\
\hline Student 25 & 63 & 86 \\
\hline Student 26 & 66 & 86 \\
\hline Student 27 & 64 & 84 \\
\hline Student 28 & 61 & 86 \\
\hline Student 29 & 56 & 86 \\
\hline Student 30 & 53 & 84 \\
\hline Student 31 & 54 & 86 \\
\hline Student 32 & 60 & 86 \\
\hline Total & 1364 & 2283 \\
\hline Average & $\Sigma X=42,63$ & $\Sigma X=71,34$ \\
\hline
\end{tabular}

The results of the recapitulation of student learning outcomes data conducted at the pretest of using a literacy reading assessment guide on reading material, then obtained the lowest value of 17 and the highest value 66 with the number 1364 with an average of $42.63 \%$ 
in the criteria of "sufficient". Meanwhile the recapitulation of student learning outcomes data in posttest using the development of a reading literacy assessment instrument developed that obtained the lowest value of 41 and the highest value of 86 with the number of 2283 with an average of $71.34 \%$ in the criteria of "good".

From the results of the pretest giving to students before using the reading literacy assessment guide book on the reading material obtained a score of 1364 with an average of $42.63 \%$ in the "sufficient" category assessment criteria which meant that the scores achieved by students in reading material did not meet expectations but needed improved again.

Table 5. Distribution of Frequency of Pretest Value of Learning Outcomes Reading Material before Using the Reading Literacy Assessment Instrument

\begin{tabular}{|l|l|l|}
\hline Interval & Frequency & Percentage \\
\hline $17-22$ & 7 & $22 \%$ \\
\hline $23-28$ & 2 & $6 \%$ \\
\hline $29-34$ & 0 & $0 \%$ \\
\hline $35-40$ & 4 & $13 \%$ \\
\hline $41-46$ & 4 & $13 \%$ \\
\hline $47-52$ & 4 & $13 \%$ \\
\hline $53-58$ & 3 & $9 \%$ \\
\hline $59-64$ & 7 & $22 \%$ \\
\hline $65-70$ & 1 & $3 \%$ \\
\hline $\mathbf{\Sigma}$ & $\mathbf{3 2}$ & $\mathbf{1 0 0 \%}$ \\
\hline
\end{tabular}

Based on the table, it can be seen that students who get 17-22 scores amount to 7 people or $22 \%$ while those who get grades $23-28$ are 2 people or $6 \%$, who get $35-49$ scores of 4 people or $13 \%$, who obtained a value of 41-46 totaling 4 people or $13 \%$, who obtained a score of 47 52 totaling 4 people or by $13 \%$. Those who get 53-58 are 3 people or $9 \%$, while those who get $59-64$ are 4 or $13 \%$. For the acquisition of 65-70 values, there are at most 1 person or $3 \%$. The total number of students is 32 people. The distribution table above will be displayed in the form of a histogram to make it clearer. This will be seen in Figure below.

Figure 3. Distribution of Frequency of Pretest Value of Learning Outcomes Reading Material before Using the Reading Literacy Assessment Instrument

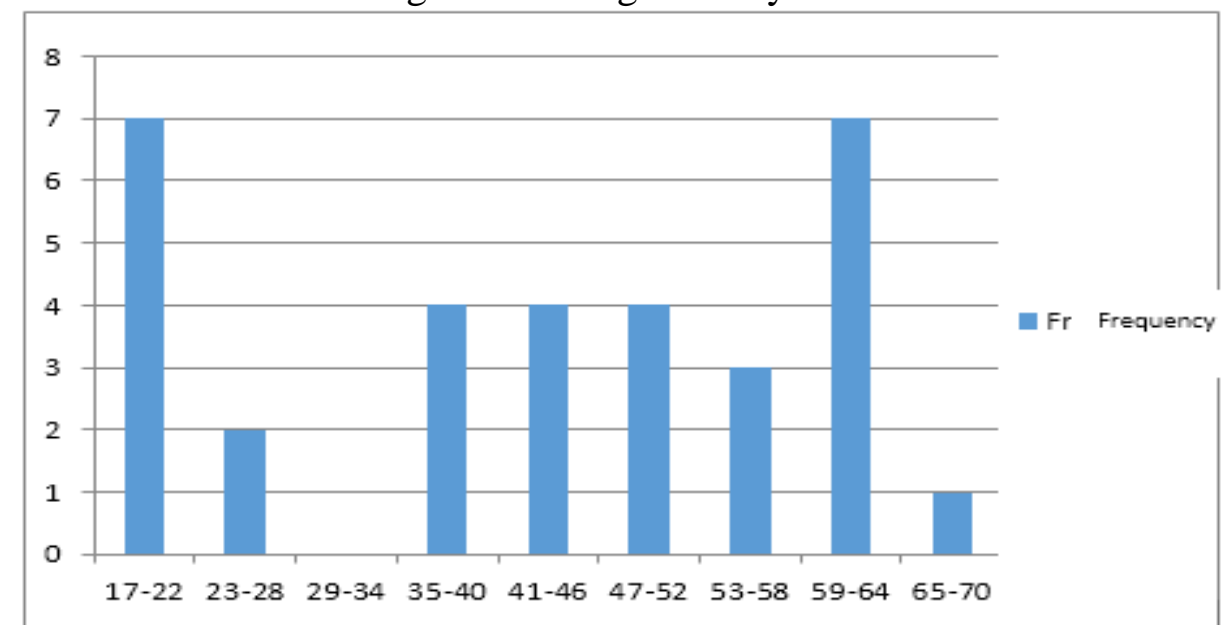


Figure 4. Histogram Frequency of Pretest Value Learning Outcomes Reading Mmaterial

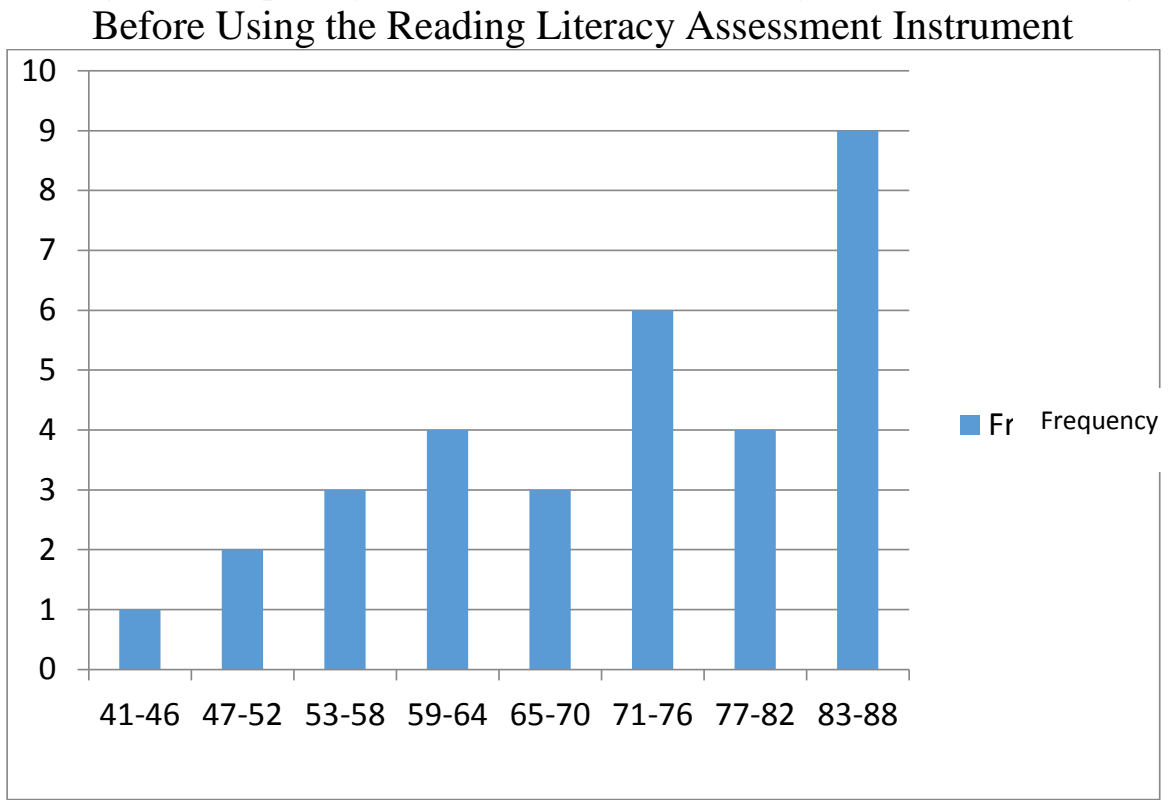

Table 6. Effectiveness of Reading Literacy Development

\begin{tabular}{|l|l|l|}
\hline No. Student & Pretes & Postes \\
\hline Student 1 & 36 & 74 \\
\hline Student 2 & 24 & 63 \\
\hline Student 3 & 47 & 51 \\
\hline Student 4 & 18 & 58 \\
\hline Student 5 & 21 & 57 \\
\hline Student 6 & 42 & 77 \\
\hline Student 7 & 61 & 60 \\
\hline Student 8 & 44 & 61 \\
\hline Student 9 & 61 & 73 \\
\hline Student 10 & 22 & 41 \\
\hline Student 11 & 39 & 72 \\
\hline Student 12 & 48 & 72 \\
\hline Student 13 & 39 & 81 \\
\hline Student 14 & 44 & 62 \\
\hline Student 15 & 44 & 71 \\
\hline Student 16 & 23 & 81 \\
\hline Student 17 & 22 & 79 \\
\hline Student 18 & 36 & 65 \\
\hline Student 19 & 21 & 75 \\
\hline Student 20 & 22 & 69 \\
\hline Student 21 & 17 & 53 \\
\hline Student 22 & 48 & 69 \\
\hline
\end{tabular}




\begin{tabular}{|l|l|l|} 
Student 23 & 47 & 51 \\
\hline Student 24 & 61 & 84 \\
\hline Student 25 & 63 & 86 \\
\hline Student 26 & 66 & 86 \\
\hline Student 27 & 64 & 84 \\
\hline Student 28 & 61 & 86 \\
\hline Student 29 & 56 & 86 \\
\hline Student 30 & 53 & 84 \\
\hline Student 31 & 54 & 86 \\
\hline Student 32 & 60 & 86 \\
\hline Total & $\mathbf{1 3 6 4}$ & $\mathbf{2 2 8 3}$ \\
\hline Average & $\mathbf{\Sigma X}=\mathbf{4 2 , 6 3}$ & $\mathbf{\Sigma X}=\mathbf{7 1 , 3 4}$ \\
\hline
\end{tabular}

Based on the analysis of the data contained in the attachment to the results of data analysis on the initial test (pretest) students obtained a total score of 1364 with an average of $42.63 \%$ in the criteria of "sufficient", while the data analysis in the final test (posttest) obtained data of 2283 with on average $71.34 \%$ on the criteria of "good".

\section{Conclusion}

The development of instrument of reading literacy assessment on the PISA reference is a direct assessment because students immediately show evidence of mastery of competencies when the assessment is conducted. The product of the reading literacy assessment instrument on the PISA reference was generated through the development stages which referred to the Borg and Gall development model and then validated by a team of material experts, evaluation experts and language experts. The product of the reading literacy assessment instrument on the PISA reference developed in the text reading material for second semester students in Medan Quality Private University fulfills the requirements and is eligible to be used based on material validation including the eligibility of $88 \%$ into the excellent category, instrument language and writing $97 \%$ with the category is very good, the feasibility aspect of presentation has a percentage of $94 \%$ with a very good category, and supporting material has a presentation of $88 \%$ with a very good category. The overall average is $92 \%$ in the excellent category.

The pattern of reading literacy assessment on the PISA reference in reading text material is classified as very good and according to the needs of students to improve reading speed and a high level of understanding in reading, judging from the response of 2 lecturers who average $89.17 \%$ with very good criteria. Second semester students have an average of $71.34 \%$ and 32 students, a percentage of $28 \%$. The level of understanding of students is still lacking and therefore it is necessary to assess literacy in PISA reading to support a high level of understanding. The use of reading literacy assessment increases the results of high-level understanding of students, this is indicated by the results of student scores after using the reading literacy assessment on the PISA reference was 2283 compared to the results before 1364. 
Budapest International Research and Critics in Linguistics and Education (BirLE) Journal

Volume 2, No 2, May 2019, Page: 372-387

e-ISSN: 2655-1470 (Online), p-ISSN: 2655-2647 (Print)

www.bircu-journal.com/index.php/birle

emails: birle.journal@gmail.com

birle.journal.qa@gmail.com

\section{References}

Abidin, Yunus, Tita Mulyati and Hana Yunansah. 2017. Pembelajaran Literasi Strategi Meningkatkan Kemampuan Literasi Matematika, Sains, Membaca, dan Menulis. Jakarta: Bumi Aksara

Alwan Wibanto. 2013. Menumbuhkan Minat Baca \& Tulis Mahasiswa Pustakaloka. Volume. 5, No.1. P: $125,128$.

Ambarita, Biner \& Wanapri Pangaribuan. 2013. Kemampuan Membaca dan Sikap Profesional Dalam Peningkatkan Mutu Pendidikan. Medan : Alfabeta

Borg and Gall.2003. Educational Research, An Introduction. New York and London. Longman Inc

Bungin, Burhan. 2013. Metodoli penelitian sosial dan Ekonomi : Format-format Kuantitatif dan Kualitatif untuk Studi Sosiologi, Kebijakan, Publik, KOmunikasi, Manajemen, dan Pemasaran. Jakarta: Kencana Prenada Media Group

Chi-An Tung \& Shu-Ying Chang. 2009. Developing Critical Thinking Trough Literature Reading Feng Chia Journal of Humanities and Social Sciences. No.19. P: 288

Covacevich, Catalina. 2014. How To Select An Instrument For Assesing Student Learning. Amerika : Inter-America Development Bank.

Gulo, W. 2002. Strategi Belajar Mengajar. Jakarta : Gramedia Widiasarana Indonesia

Hadi, Shafwan Umri. 2011. Teori Sastra (Puisi dan Prosa). Medan : Mitra

Imroatus Solikhah. 2016. Pengembangan Model Kurikulum Pendidikan Bahasa Inggris Berbasis KKNI. Volume. 8, No. 1. P: 21.

Kemendikbud. 2017. Permendibud No.22 Tentang Penilaian Hasil Belajar oleh Pendidik dan Satuan Pendidikan Pada Pendidikan Dasar dan Menengah. Kementrian Pendidikan dan Kebudayaan Republik Indonesia. Jakarta.

Leino, Kaisa. 2014. The Relationship Betwen ICT Use and Readeng Literacy. Firlandia: Jy Väskylä Universitas Press Syväskylä.

Mansyur, at el. 2015. Asesmen Pembelajaran di Sekolah Panduan bagi Guru dan Calon Guru. Yogyakarta: Pustaka Pelajar

Mulyasa, E. 2006. Implementasi Kurikulum 2009 Panduan Pembelajaran KBK. Bandung : Remaja Rosda Karya

Musfiroh, Tadkirdatun and Listyorini. 2016. Konstruk Kompetensi Literasi untuk Siswa Sekolah Dasar. Jurnal Litera. Volume. 15, No.1. P: 2

Sari Esti Swastika. 2016. Mengoptimalkan Kembali Literasi Sastra di Perguruan Tinggi Perlukah?. Yogyakarta : KNBS III

Siswati. 2010. Minat Membaca Pada Mahasiswa (Studi Deskriptif pada Mahasiswa Fakultas Psikologi UNDIP Semester I). Volume. 8, NO. 2 P: 124

Sugiyono. 2015. Metode Penelitian Pendidikan. Bandung: Alfabeta.

Suryaman, Maman. 2014. Analisis Hasil Belajar Peserta Didik Dalam Literasi Membaca Melalui Studi Internasional (PRILS) 2011. Volume. 14, No.P: 4

Tegeh, Made at el. 2014. Model Penelitian Pengembangan. Yogyakarta: Graha Ilmu

Undang-undang Republik Indonesia No.12 Tahun 2012 Tentang Pendidikan Tinggi

Uno, Hamzah B, Satria. 2014. Assessment Pembelajaran . Jakarta : Bumi Aksara

Tarigan, Henry Guntur. 2008. Membaca Sebagai Suatu Keterampilan Berbahasa. Bandung : Angkasa Bandung

Tri, Endah Priyatni. 2015. Membaca Sastra Dengan Ancangan Literasi Kritis. Jakarta : Bumi Aksara

Tri, Endah Priyatni \& Nurhadi. 2017. Membaca Kritis dan Literasi Kritis. Tangerang : Tira Smart Widiatmoko, Irwan. 2011. Super Speed Reading Metode Lengkap dan Praktis untuk Meningkatkan Kemampuan Membaca. Jakarta : PT. Gramedia Pustaka Utama 